\title{
The First Forty Years of the Heterocyclic Group of the Royal Society of Chemistry
}

Professor Emeritus Gurnos Jones, School of Physical and Geographical Sciences, Lennard-Jones Laboratories, Keele University, Staffordshire, ST5 5BB, U.K.

In 1967 the idea of specialist subject groups was comparatively new. To test the waters, Professor A.R. Katritzky and Dr. G. Jones held a meeting at Keele University at which 125 chemists voted to propose to the Chemical Society Council the formation of a Subject group for those interested in the study of heterocyclic compounds, hereafter called the Heterocyclic Group. The proposal was accepted by the Council on the 5th April, 1967, a committee was formed, with Professor Alan Katritzky as Chairman and Dr. Gurnos Jones as Secretary/Treasurer, and a first half-day meeting held before the main Autumn meeting of the Chemical Society in Durham on 19th September. Much more detail is given in the article on the history of the group which is the first article in this issue of Arkivoc, but the Group has been an enormous success with an average of four meetings (one day and longer) each year. A pattern soon developed with a meeting in London in January, and a meeting at an industrial site in the summer. Industry, particularly the pharmaceutical industry has from the first been very supportive. In early years the group used one day during the Autumn Meeting of the Chemical Society (later the Royal Society of Chemistry), but in later years this has been replaced by a meeting with postgraduate student presentations, of very high quality. The first longer meeting was held in Grasmere in the Lake District, organised by Dr. Otto Meth-Cohn, and this has been a huge success with excellent lecturers from all over the world. This issue of Arkivoc is timed to coincide with the eighteenth of these biannual meetings in May, 2007. In 1988 the first of a further biannual series of longer meetings was started in collaboration with the Heterocyclic Group of the Italian Chemical Society, held in Sicily, and these have continued, held alternately in Italy and the British Isles. As of 2005, the name of the Group has been changed to Heterocyclic and Synthesis group, to reflect widening interests; with membership over 700 and a vibrant programme, the Group looks set for at least another forty years of exciting chemistry. This issue of Arkivoc is made up of contributions (written and artistic) from Chairmen and Secretaries of the Group as a tribute to its first forty years, and will, hopefully, coincide with the eighteenth Grasmere meeting, in 2007. 


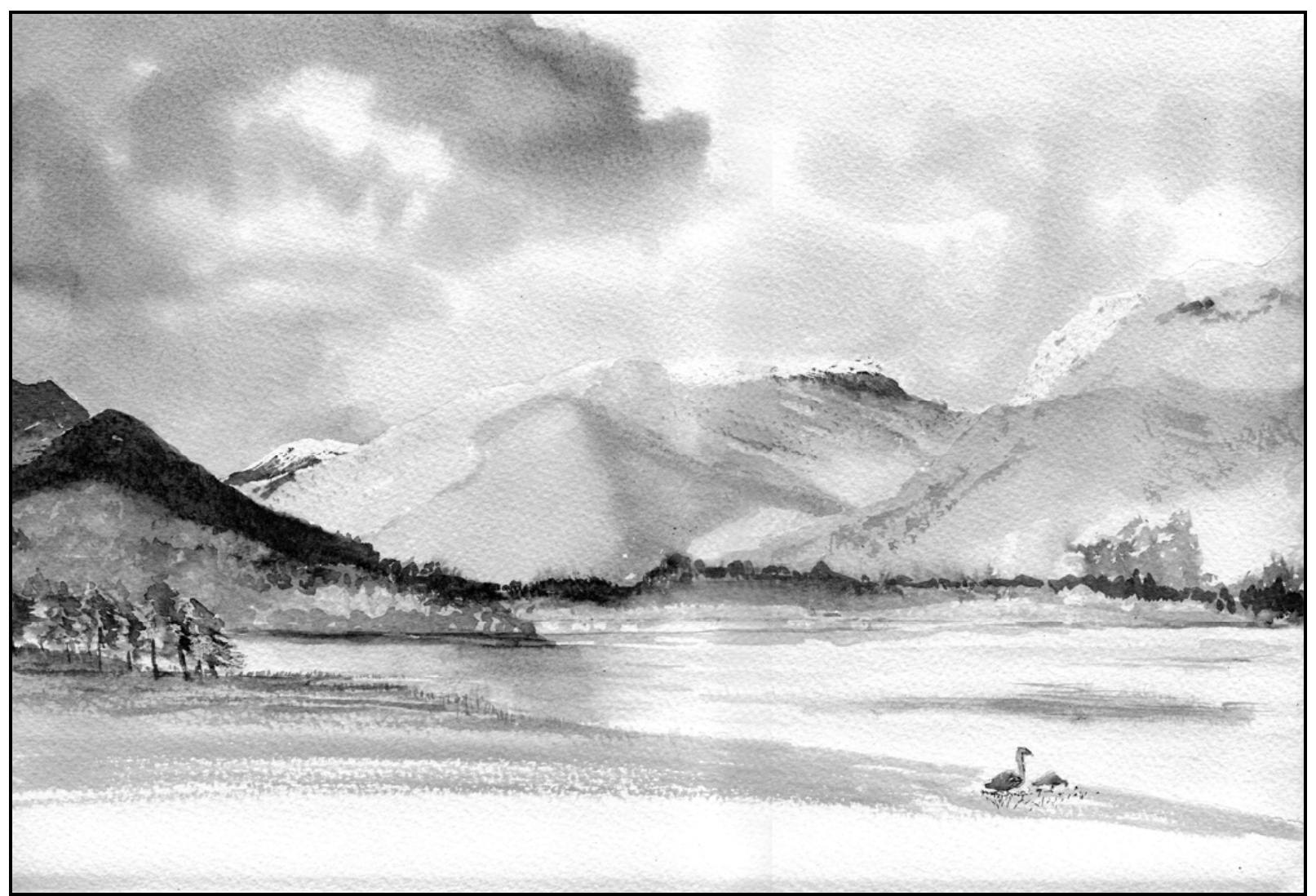

Grasmere in May. Painted in water soluble black ink by Otto Meth-Cohn 


\title{
Forty years on A history of the heterocyclic group of the Royal society of chemistry
}

\author{
Gurnos Jones
}

School of Physical Science and Geography, Lennard - Jones Building, Keele University, Keele, Staffordshire, ST5 5GB, U.K.

\begin{abstract}
An account of the progress of the Heterocyclic Group, from its beginning in 1967 under the Chemical Society to its present status under the Royal Society of Chemistry.
\end{abstract}

\section{Introduction}

During a stroll in the rain, during the seventeenth Grasmere meeting, Alan Katritzky and Gurnos Jones realised that 2007 would be the 40th Anniversary of the formation of the Heterocyclic Group. They felt that a special issue of Arkivoc might be commissioned to celebrate this anniversary and this proposal was put to the Chairman and Secretary of the Group. It was hoped that most of the surviving Chairmen and Secretaries would contribute a research paper, and that the original Group Secretary would contribute a history. Of the Chairmen and Secretaries contacted, all replied favourably, and all who could provide a paper have done so. The account of the early years draws heavily on the history prepared for the 21st Anniversary by the same author, but this had a limited circulation and has been further annotated.

\section{Beginnings}

In late 1966, Professor Alan Katritzky, having established the School of Chemistry at the new University of East Anglia, was touring the outlying provinces, discussing with various eminent heterocyclic chemists the idea of forming a Heterocyclic Discussion Group within the Chemical Society. The concept of specialist Subject Groups was a novelty viewed with suspicion by many Fellows, partly from fear of fragmentation of the Society, and he met with little encouragement. A visit to Keele and a discussion with Dr. Gurnos Jones produced a more encouraging response, and the gang of two decided to arrange a scientific meeting to float the idea to a wider public. The meeting was held at Keele, and Professors C.W.Rees (Leicester) and G.W. Kenner (Liverpool), and Drs. K. Schofield (Exeter) and D.H. Reid (St. Andrews) agreed to speak. The meeting was held on March 22nd, 1967; the registration fee was twenty five shillings (£1.25) and bed and breakfast was available for twenty two shillings and six pence (£1.125). The meeting 
was a great success, one hundred and twenty five chemists attending, and with excellent lectures and discussion. Another thirty one chemists unable to attend, wrote in to offer support. After the scientific meeting there was a lively discussion in which conflicting views were expressed, some distinguished attendees speaking against the proposal, but a vote showed an overwhelming support for a motion to seek permission from the Chemical Society Council to form a Heterocyclic group. A provisional committee, which eventually became the first formal committee was elected, with Alan Katritzky as Chairman, Gurnos Jones as Secretary/Treasurer, and a committee of Drs. Gordon Cheeseman (Queen Elizabeth College), Justus Landquist (I.C.I. Pharmaceuticals), Ken Schofield (Exeter), and Professor Hans Suschitzky (Salford). The Council of the Chemical Society approved the formation of the Group on the 5th April, 1967, and it became necessary to arrange meetings and find funds, since there was no subscription. In retrospect it was somewhat of a financial gamble for a youngish academic Treasurer, and there was much relief when income began to come in. For the first meeting in 1967 we attached ourselves to the Chemical Society Autumn meeting at Durham holding a session with eleven short papers on the afternoon before the main meeting started. This was followed by a meeting in January 1968 at Queen Elizabeth College in Kensington, and another at I.C.I. Pharmaceutical Division at Alderley Park in the summer of 1968. Thus, within the first year a successful pattern was established. The January meeting, mostly in London and the meeting at an industrial site have continued to the present day. More ambitiously, the group Secretary negotiated a full day as part of the 1968 Chemical Society Autumn meeting at Keele, with a registration fee covering the one day only, and this encouraged other groups to participate, making for a much more varied programme. At these meetings there were no main lectures, only submitted short papers. After the next January meeting in London the group felt sufficiently solvent to risk a larger event with two plenary lectures, by Professors Emanuel Vogel and Nelson Leonard. The meeting was held at Welwyn Garden City, attracted over 200 participants, and was sponsored by the four local companies Glaxo, Roche, Smith and Nephew, and Smith, Kline, and French. A number of the early meetings were modelled on the Faraday Discussions. The detailed abstracts were circulated before the meeting, the presenter was limited to five minutes and there was fifteen minutes of discussion. Thus the discussion could be much more informed, as participants had time before the meeting to research their questions. I regret the demise of this type of meeting, but the pressure on the Secretary to obtain and reproduce long abstracts in time was too great. The first era of the group can be conveniently said to have ended with the retirement in 1969 of Alan Katritzky as Chairman, to be replaced by Charles Rees, and, a year later, by the retirement of Gurnos Jones as Secretary/Treasurer to be replaced by Otto Meth-Cohn. By this time the membership was well over 300 and the bank balance healthy. ${ }^{1}$ The full list of subsequent Chairmen and Secretaries can be found in Appendix 1. It is to these that the group owes its longevity and success. From here the history can best continue by considering the progress of the different types of meeting. 


\section{One Day Meetings}

There were two types of one day meeting in 1970, the January meeting and the industrial meeting, which were later joined in 1986 by an annual meeting for postgraduate presentations, held in early summer.

The January meetings were held in London, apart from one excursion to Aston. They have to some extent reflected the fate of academic chemistry departments, moving around the colleges of London University as their departments were closed. Thanks to our early committee members Gordon Cheeseman and Clive Bird we were able to use the pleasant Kensington Campus of Queen Elizabeth College for our first London meeting in 1968 and continued there until 1994, although by this time it was the Kensington campus of Kings College. By this time also the Queen Elizabeth chemistry department had closed with some members relocated to the Strand campus of Kings College and it was natural to transfer the January meeting also. At the risk of describing the holding of Heterocyclic Group meetings as the kiss of death we should mention that there was one at Queen Mary College in the East End, which has also closed its chemistry department. After a few years wandering the corridors of Kings College, Strand, and one meeting at the Guy's campus, the seemingly inevitable closure meant a final relocation in 2004 to Imperial College, and if continued hospitality is offered, the January meeting seems safe until the end of chemistry in London! After the first few meetings, which consisted entirely of short submitted papers, increasing wealth allowed the inclusion of plenary lecturers. As the meetings are on Friday, the attraction of a weekend in London plus attendance at Charles Rees's house in Holland Park for a reception has made plenary lecturers easy to find. Probably the most memorable January meeting was in 1982 and coincided with a blizzard. Out of one hundred and twenty registered participants, one hundred and five managed to arrive, in some cases by lunchtime, and we believe that all reached home. The Manchester train reached Stoke around 2 a.m. and your author walked up the hill to Keele around 3 a.m. Malcolm Stevens left the train in the outskirts of Birmingham and was seen climbing down the embankment and disappearing along a deserted road. This anecdote is included to provide a contrast between British Rail (then) and various private enterprises (now), because the train did reach its destination! Traditionally the Annual General Meeting has been held after lunch at this meeting; confidence in the Committee is such that the meeting rarely lasts more than twenty minutes and has been known to be over in ten. However for some years a Member attended regularly to query the accounts, thus preserving democracy, although no-one can recall seeing him at any other scientific meetings. Returning to the chemistry reported at the January meetings, some of the early sessions had themes such as "Pyrroles and Azoles", "Physico-chemical techniques and Structure-Activity correlations", "Synthetic Strategies to Unusual Heterocycles" and "Organometallic and Other Aspects of Heterocyclic Chemistry". The meeting in 1988 was treated as a celebration of our 21st year, and all speakers were former Chairmen or Secretaries of the Group. A photograph taken at the meeting is reproduced below. A list of speakers who gave plenary or longer lectures at one day meetings is included as Appendix 2. A loss of some archival material has allowed 
only estimates of the numbers of shorter contributions at January meetings, but there have been around 135.

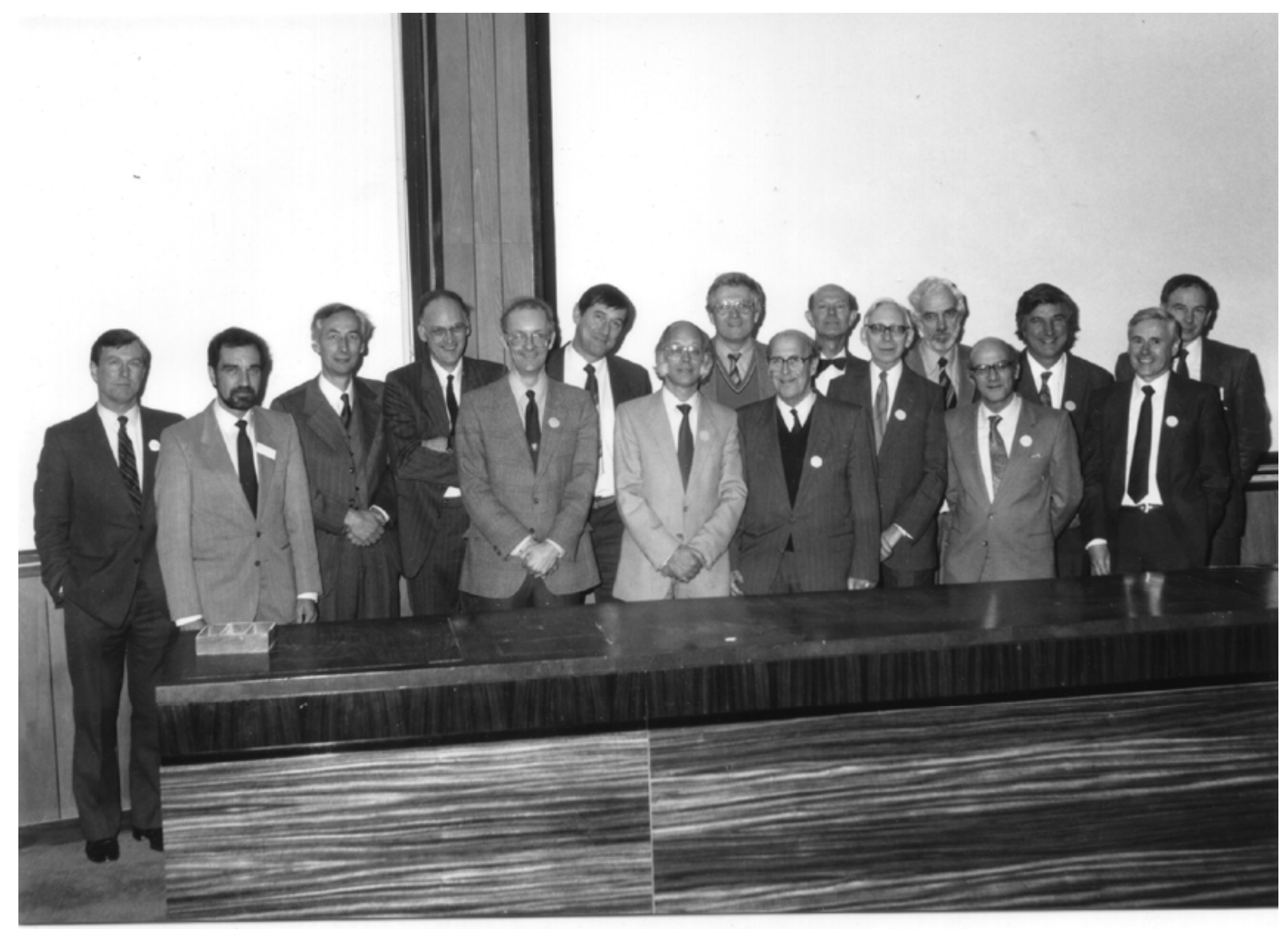

From left to right; John Cadogan, Dick Storr, John Boulton, Alan Jones, Hamish MacNab, Roger Newton, Otto Meth-Cohn, Ron Grigg, Hans Suschitzky, Charles Rees, Gurnos Jones, George Wibberly, Anthony Roe, Alan Katritzky, Dick Chambers, Malcolm Stevens

The Industrial Meetings have been a tribute to the relevance of heterocyclic chemistry to industry in general and the pharmaceutical and agrochemical areas especially. It is worth listing the firms where we were welcomed, because they, like those of the January meetings, reflect the changing face of chemistry in the United Kingdom. The first hosts were I.C.I. Pharmaceutical Division at Alderley Park in 1968; subsequently the company have been the most consistently welcoming first as Zeneca Pharmaceuticals, and now as Astra Zeneca. The pattern established was of a comfortable lecture room, help with the costs of plenary lecturers, and an excellent lunch, suspected of being a major attraction. Other pharmaceutical companies visited were Rhone Poulenc, Smith, Kline, and French, Beecham, (Smith, Kline, Beecham), Glaxo (GlaxoWellcome, GlaxoSmithKline), Fisons Pharmaceuticals (Zeneca, AstraZenaca), Eli Lilly, Organon (one of our few visits to Scotland), Merck, Sharpe, and Dohm, and Novartis. In the area of agrochemicals, the Group has visited ICI (Zeneca, Astro, Syngenta), Shell Biosciences 
(closed), and Schering Agrochem, and in other areas I.C.I. specialities and Aston Molecular. This list shows second or third visits to the same company in parenthesis, and is included to show the huge changes due to amalgamations, takeovers, and closures which industry in the United Kingdom, especially the pharmaceutical industry, have suffered over the last forty years.

\section{Postgraduate Meetings}

The Group has promoted postgraduate participation from the start, with postgraduates encouraged to attend meetings and ask questions, but there were at first no meetings specifically aimed at them. In 1986 the Group held its first meeting at which all presentations were by postgraduates, at Aston University. Ten students were selected to give oral presentations and there were eight posters. The meeting was a great success with an audience of one hundred and fifty. The second meeting at Keele University saw one hundred and thirty seven participants followed by Nottingham (one hundred and eighty nine), Sheffield (almost two hundred), UMIST (one hundred and thirty), and Leeds (ninety). These very high attendances have not been maintained, the average attendance varying between a low of forty and a high of eighty, which may reflect the increased difficulty of funding postgraduate research and the considerably reduced number of chemistry departments as vice chancellors become more cost conscious. Subsequent meetings have been held at Loughborough (twice), Birmingham, Leicester, Warwick, Leeds, Keele, Reading, Cardiff, York, Nottingham; at Manchester and Sheffield there was a plenary speaker, funded from an RSC bequest. Possibly the last in the familiar format was at Birmingham (2005). The number of speakers has remained constant around 10, and the presentations have been universally excellent; it has been regrettable that the participation by academics and industrialists has declined. As a result of this decline it was proposed at the AGM in 2006 that the Postgraduate and the Industrial meetings should be combined, thus increasing the audience and drawing in more members from industry, but with the inevitable result of reducing the number of postgraduate contributions. Since this meeting will be held after this article has been submitted, it may not be possible to report the results. In the section on the Grasmere meetings, it is reported that the first such meeting was modelled on the Gordon Conferences, but it must be emphasised that as a matter of policy, unlike the Grasmere meetings, the Gordon Conferences were never available to postgraduates. In all, almost 200 postgraduates have been able to present their work orally, with many more presenting posters at Grasmere, at the Anglo-Italian meetings, and in association with other occasional meetings, so that the Group has made a valuable contribution to postgraduate education in the U.K.

\section{International Meetings}

While many of the meetings of the Group have had speakers and attendees from abroad, the Group has run two series of international meetings at Grasmere in the English Lake District and jointly with the Organic Chemistry division of the Società Chimica Italiana. 


\section{Grasmere meetings}

Otto Meth-Cohn returned from a visit to the Gordon Conference on Heterocyclic Compounds convinced, as he put it, that we could do better. Consideration of this typically confident statement will be left until the end of this section. The plan of the Gordon Conferences has always been to have all participants resident, to have scientific sessions morning and evening. with the afternoons free for recreation of various sorts. Otto reports that he considered a number of possible sites for the conference, in the Lake District and elsewhere before settling on Grasmere in the English Lake district, a popular holiday resort with many hotels and, most importantly, a village hall, in which the meetings could be held. ${ }^{2}$ For the first meeting in 1983, and early subsequent meetings, the group owed much to Councillor Albert Bowers and his wife, who handled any local difficulties and helped with the organisation. The meetings are biannual and have always been held over a long weekend in early May, when the weather is mainly good, ${ }^{3}$ and, being out of the main season, the hotels have space and can offer lower rates. As the number of participants has risen to the capacity of the village hall the Group has filled 5 hotels, centred on the Red Lion and, after its rebuilding in the late seventies, the Wordsworth. The first meeting established most of the programme, with a reception in the Red Lion on Thursday evening, scientific sessions from 9.00 to 12.30 and from 7.15 (optimistically since dinners can be slow) to a nominal 9.30 p.m. On Sundays and Mondays, morning sessions only are held, the participants dispersing after lunch on Monday. There are many memorable moments, but most participants will remember the icy temperatures in the early morning village hall, especially if someone forgot to turn on the rather inadequate heating. One (nameless) secretary forgot to book the village hall, and the meetings were held that year in a tent on the Wordsworth hotel lawn, heated by what appeared to be a large jet engine. The RAF low altitude training flights were even more deafening than usual, but fortunately there were no real Lakeland showers or the speakers would have been inaudible. In 1981 an airline strike landed overseas speakers at various times at many distant points. Most passed the initiative test and found trains or taxis and the programme was not affected. The contributions, particularly the plenary lectures, have been outstanding (see Appendix 3), and Grasmere is known world wide as one of the best such meetings. There have been problems for the session Chairmen, notably with Saturday evening speakers who wished to carry on when the audience wished to go to the bar; ${ }^{4}$ the outstanding lecture for length was by Professor Kametani who had allegedly 95 slides, each one with up to 8 complex alkaloid structures. Two distinguished former Chairmen of the Group left at nominal full time, took a slow walk around the village and returned to find the speaker still in full flow. The meetings have always been notable for audience participation (the concept of "irreversible lethality" introduced by one speaker raised a question about the possibly more interesting concept of "reversible lethality" and a suggestion from Charles Rees that it reminded him of the concept of "hereditary impotence"). This is a suitable point to mention the Saturday evening lecture at the eleventh meeting, which was given by Charles Rees, which has led to the eponymous Charles Rees Lectures, given by friends, and with the dedicatee still very much in attendance. 
An important part of the recreational activity since the first meeting has been the series of walks over the fells, although the first series did not engender optimism. The first afternoon found some fifty chemists and families (over sixties and under fives) scattered over the side of Silver Howe and Castle Howe in a thunderstorm; gear thought suitable for mountain walks included town shoes, smart coats, and umbrellas. On the Sunday after this Otto Meth-Cohn devised and led (for a while) a walk from Grasmere to Borrowdale over two high passes; at a crucial point (so Otto maintains) Alan Katritzky took over and led the party at $90^{\circ}$ to the right of the correct route down towards Thirlmere. After this diversion the group were very late returning, arriving for the second course of the banquet. The Katritzky Memorial Walk has taken the correct route without major incident at every subsequent meeting, although Alan Katritzky and John Greenhill left early on one walk and were seen approaching the main party from a direction which indicated that they had erred in a direction $90^{\circ}$ to the left this time. To celebrate the tenth Grasmere meeting, Otto Meth-Cohn and the author carried six bottles of champagne on the Memorial Walk, and were able to share them with all participants at the point where Borrowdale finally comes into view. Ichiya Ninomiya took part in the first walk at the sixth meeting wearing a smart suit and town shoes and carrying a large tripod. By the next meeting he had purchased boots and battled his way over Fairfield, to much applause. A reverse walk, arriving in Grasmere, was led by Malcolm Stevens in 2003; his party met those taking the conventional approach, led by various Joneses, at the highest point. The traditional route, where participants arrive with relief at the tea shop in Stonethwaite, seems to have prevailed.

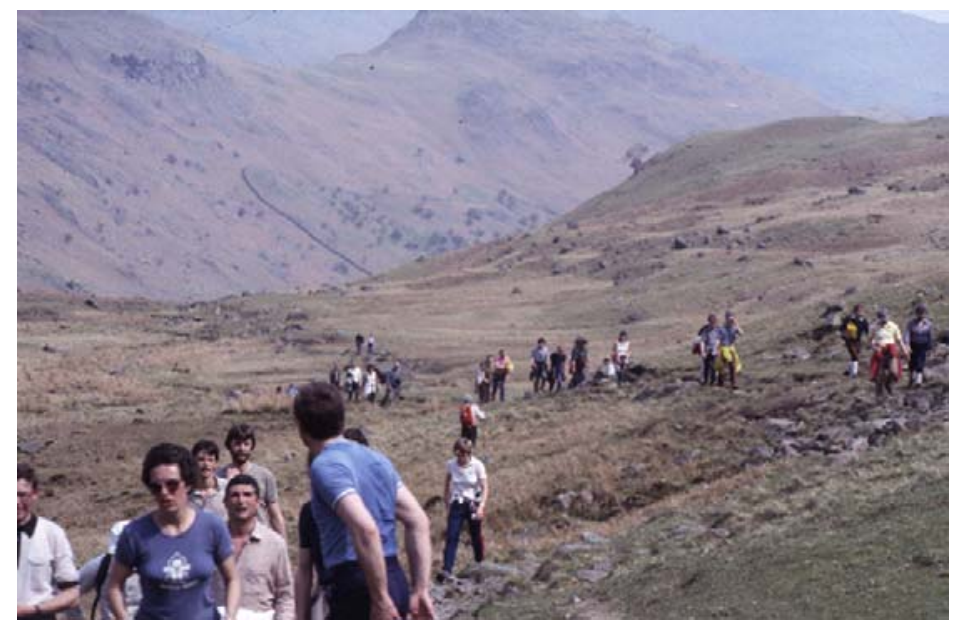

UP, SUN, 1985

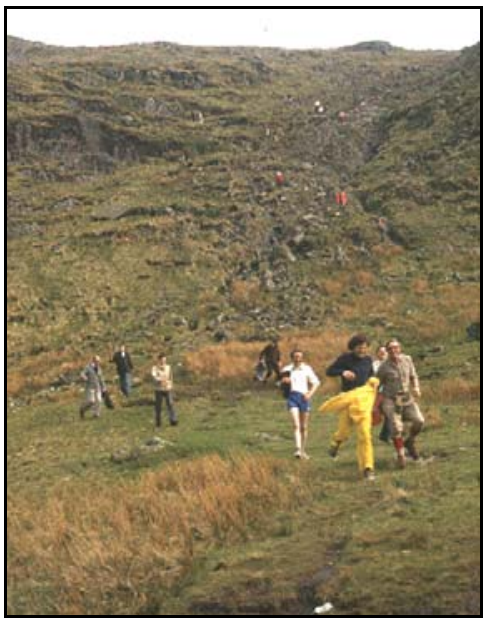

DOWN, RAIN, 1981

Views of the Katritzky Memorial Walk; Victor Snieckus leading the charge down to the tea shop in Stonethwaite. Careful inspection of both pictures will reveal walkers straggling back to the horizon. 
The other major social event has always been the Sunday evening banquet, illuminated by a series of excellent after dinner speeches by Charles Rees, ably assisted at first by John Cadogan, then later by David Evans, and for the last four meetings by Stuart Warren. It has been a matter of some regret that these speeches were never recorded, although some material may well have been actionable. The pleasant surroundings have also ensured a regular coterie of partners enjoying a social programme.

An effort was made from the beginning to involve postgraduate students, supported by bursaries, who acted as projectionists and general labourers, but also contributed posters. This is in contrast with the Gordon Conferences where postgraduates were not eligible. Returning to the original question, comparisons with the Gordon Conference are largely irrelevant; the objectives have differed and the increase in size of the Gordon Conference must have compromised the early ethos, in which the author remembers that one could meet most of the 100 or so participants at communal meal times. Fortunately the limited accommodation and Village Hall capacity, even with the balcony, will continue to keep the Grasmere meetings of a manageable size. The major worries must be the increasing hotel costs and the difficulty of obtaining outside funding as the pharmaceutical companies, our main donors, amalgamate and close. It seems a far cry from the first meeting where a grant of three thousand dollars was given by the U.S. Army European Office to help with travel expenses for speakers from the U.S.A.

\section{The Anglo-Italian Meetings}

This section is in danger of reading more like a holiday brochure than a sober history, but the list of plenary lecturers in Appendix 3 will indicate the amount and quality of the science. The committee was approached in 1986 by Professor Uccella from Calabria with the suggestion that a joint meeting might be held between the Chemical Society Heterocyclic Group and a similar Group from Società Chimica Italiana. The first meeting was held at Catania in Sicily, in the spring of 1988, and was an immediate success, attracting one hundred and five chemists from Italy and thirty seven from the rest of the world. It was decided that the meeting should be biannual, alternating between Italy and the UK, and held in the years between Grasmere meetings. Those of us who visited Catania were aware of the difficulty of matching the setting, the hospitality, the trip up Etna, and the wonderful weather, but the committee responded by holding the second meeting during the Chemical Society's Annual meeting in Belfast. This second meeting was successful, but the Italian response was a second meeting in Sicily, this time in a hotel complex on the Mediterranean outside Sciacca. Again there was an good turn out from the U.K. (forty five), the chemistry, hospitality and weather were excellent, although there were two potential flash points. In the first the Italians beat the U.K. at football by 4-1, in spite of Malcolm Stevens's heroic goal-keeping. The second was on the excursion when we were entertained to an historic puppet show in which the Normans fought the Saracens. After a few minutes the U.K. contingent decided to cheer for the Normans (particularly loudly when a Saracen head was cut off), only to discover subsequently that this was a serious cultural event for Italians and apologies had to be offered (England is well-known for its football hooligans). The 
fourth meeting was held in Jersey and at last offered competition in the holiday environment stakes; again a good attendance, good chemistry, and warm weather. A fifth meeting in Italy at Numana on the Adriatic, kept up the theme of sun, sea, and sand, with good lectures, the field being widened to include those from outside of Italy and the U.K. It was also possible to take some postgraduate students on bursaries who presented posters. A meeting in Galway followed, with typical Irish hospitality, including a memorable boat trip down Lough Corrib with salmon and baked potatoes cooked in the tiny galley. Back in Italy at Folgaria in the mountains to the north of Italy the weather for once was a little below par; an attendee remembers the conference centre above the swimming pool with a faint, suitably chemical smell of chlorine. The last few meetings have been in Edinburgh, in Urbino (with a record attendance of one hundred and sixty eight), and at Harrogate. Full details of the Harrogate meeting may not be available before the deadline for this article. The plenary lecturers are listed with those of the Grasmere meetings, in Appendix 3.

\section{Further Developments and General Comments}

One of the most important decisions recently, taken at the 2006 Annual General Meeting, was to ratify a suggested change to the name of the Group. The committee felt that the emphasis of the chemistry presented at Group meetings had always been towards synthesis and proposed to change the name to reflect this fact, and to mitigate against the formation of any second group devoted to synthesis. After a postal vote this suggestion received the support of a majority of those who replied, was accepted by the R.S.C. Council, and the new title is "The Heterocyclic and Synthesis Group”. The committee also proposed that the number of meetings per annum be reduced; the effect of this will be to combine two of the one day meetings, the Postgraduate and the Industrial, and the new format will be tested in the autumn of 2006. In spite of some gloomy forecasts, the Group still appears in good health, with over seven hundred members (we never quite reached the one thousand mark), and seems capable of reaching its fiftieth anniversary unless there is a catastrophic downward turn in chemistry in the United Kingdom. Its first forty years have certainly been successful to an extent that its progenitors could not have imagined, but in one major area it appears to have failed. In the forty years, none of the officers have been women. Indeed so far as I can ascertain there has never been a female committee member, nor, until the January meeting in 2001, a female plenary lecturer (appearing again in Harrogate in 2006, but still unique).. The lists of the contributors to the postgraduate meetings shows a normal balance of males and females, but after this the females become minority contributors, although they do attend meetings in numbers. Perhaps by anniversary fifty we may have to amend the title to Chairperson?

\section{Appendices}

I regret that the attached appendices are not quite complete, because of a loss of records for much of the 1970s. I have decided to limit lists of officials to the Chairmen and Secretaries, but this is not to ignore the considerable efforts of the Committee Members who must in all number well 
over 50. Also, in reporting only longer lectures in Appendix 2 and Appendix 3 I am not down playing the large number of contributions of length less than thirty minutes each which are the life blood of the Group's activities, but I have had neither time nor full information to assemble these.

\section{Acknowledgements}

I have had much help in preparing this History from the Chairmen and Secretaries; in particular I should like to thank Anthony Roe, whose considerable collection of documents, particularly of AGM papers, has been invaluable. Finally thanks are due to Alan Katritzky, who, as usual, made sure that the enterprise never lost momentum.

\section{References}

1. By January 1969 the treasurer felt able to offer a reduced registration fee for the meeting of fifteen shillings (£0.75) with a further reduction to seven shillings and six pence for research students "because of the satisfactory balance in hand". Professor Katritzky wishes to add this note; "In the early days financial matters were decided by majority vote of the Officers of the Group. Any extravagant expenditure suggested by the Chairman was immediately outvoted by the Secretary and Treasurer, who not surprisingly always voted together. This excellent system has much to recommend it, especially in retrospect”.

2. The Tourist Officer responsible for the Grasmere area, who was very active in encouraging the Group to use the village as a base, moved to Guernsey and appears to have made efforts to persuade the Group to move also, but fortunately these blandishments were resisted.

3. Connoisseurs of heraldry may wish to study the cover of the 7th Grasmere conference book, where the motto on the Chemical Society crest was replaced by John Boulton with the phrase "OREMUS CONTRA PLUVIUM", roughly translated as "WE PRAY THAT IT MAY NOT RAIN".

4. Malcolm Stevens donated a shepherd's crook for use by Chairmen in keeping order, but this has disappeared, possibly destroyed by a frustrated speaker. 
Appendix 1. Chairmen and Secretary/Treasurers of the Heterocyclic Group

\begin{tabular}{llll}
\multicolumn{2}{c}{ Chairmen } & \multicolumn{2}{c}{ Secretary/Treasurers } \\
\cline { 2 - 4 } A.R. Katritzky & $1967-1969$ & G. Jones & $1967-1970$ \\
C.W. Rees & $1969-1971$ & O. Meth-Cohn & $1970-1973$ \\
H. Suschitzky & $1971-1973$ & R.A. Jones & !973-1976 \\
D.G. Wibberley & $1973-1975$ & G. Tennant & $1976-1979$ \\
J.I.G. Cadogan & $1975-1977$ & M.F.G. Stevens & $1979-1982$ \\
A.H. Jackson & $1977-1979$ & A.J. Boulton & $1983-1986$ \\
G. Jones & $1979-1981$ & R.C. Storr & $1986-1989$ \\
R.F. Newton & $1981-1983$ & H. McNab & $1989-1992$ \\
R. Grigg & $1983-1985$ & R.F.C. Jones & $1992-1996$ \\
A.M. Roe & $1985-1987$ & K. Jones & $1996-1999$ \\
R.D. Chambers & $1987-1989$ & P.B. Page & $1999-2002$ \\
O. Meth-Cohn & $1989-1991$ & P. Stevenson & $2002-2005$ \\
M.F.G. Stevens & $1991-1993$ & P. O’Brien & $2005-p r e s e n t$ \\
C.J. Moody & $1993-1995$ & & \\
C.A. Ramsden & $1995-1997$ & & \\
R.Westwood & $1997-1999$ & & \\
R.A.J. Taylor & $1999-2001$ & & \\
R.F.C. Jones & $2001-2003$ & & \\
P.M. Bailey & $2003-2005$ & & \\
K.Jones & $2005-p r e s e n t$ & &
\end{tabular}

Appendix 2. Principal Lecturers at One Day Meetings

\begin{tabular}{|l|l|l|}
\hline Aggarwal, Professor V. & University of Sheffield & J 1998 \\
\hline Alexakis, Professor A. & University of Geneva & J 2001 M 2004 \\
\hline Anderson, Dr. P.S. & Merck, Sharp, and Dohme & I 1989 \\
\hline Armstrong, Professor A. & Imperial College & J 2005 \\
\hline Bailey, Professor P.D. & Heriot-Watt University & I 1993 \\
\hline Barluenga, Professor J. & University of Oviedo & J 1991 \\
\hline Beugelmans, Professor R. & C.N.R.S. Gif-sur-Yvette & I 1985 \\
\hline Blechert, Professor S. & University of Berlin & I 2002 \\
\hline Bohm, Professor C. & RWTH-Aachen & M 2003 J2006 \\
\hline Bonnett, Professor R. & Queen Mary College, London & A 1973 J 1980 \\
\hline Brown, Dr. R.F.C. & Monash University & I 1990 \\
\hline Brown, Professor T. & University of Edinburgh & J 1995 \\
\hline
\end{tabular}




\begin{tabular}{|c|c|c|}
\hline Burger, Professor K. & Technical University, Munich & J 1994 \\
\hline Butler, Professor R.N. & University College, Galway & J 1980 \\
\hline Caddick, Professor S. & University College, London & I 2004 \\
\hline Cadogan, Professor,J.I.G. & $\begin{array}{l}\text { University of Edinburgh } \\
\text { BP Research Centre }\end{array}$ & \begin{tabular}{|l|} 
A 1973 \\
Edinburgh 1979 \\
\end{tabular} \\
\hline Callot, Professor H.J. & $\begin{array}{l}\text { Louis Pasteur University, } \\
\text { Strasbourg }\end{array}$ & J 1986 \\
\hline Campbell, Professor M.M. & University of Bath & I 1981 J 1987 \\
\hline Carell, Professor T. & University of Marburg & I 2003 \\
\hline Carreira, Professor E. & ETH, Zurich & J 1999 I 2004 \\
\hline Chadwick, Dr. D.J. & Ciba Foundation & J 1989 \\
\hline Chuche, Professor J. & University of Reims & I 1983 \\
\hline Clark, Professor S. & University of Nottingham & I 2001 \\
\hline Clayden, Professor J. & University of Manchester & $\mathrm{J} 2005$ \\
\hline Craig, Professor D. & Imperial College & $\mathrm{J} 2003$ \\
\hline Crout, Professor D,H, & University of Exeter (Warwick) & J 1984,1989 \\
\hline Davies, Professor S.G. & University of Oxford & I 1993 J 2002 \\
\hline Donohoe, Dr. T. & University of Oxford & $\mathrm{J} 2003$ \\
\hline Dötz, Professor K.-H. & University of Bonn & I 1998 \\
\hline Elguero, Professor J. & CSIC Madrid & J 1985 \\
\hline Enders, Professor D. & University of Aachen & I $1995 \mathrm{~J} 2000$ \\
\hline Fleet, Dr. G.W.J. & University of Oxford & I 1992 \\
\hline Fleury, Professor J.P. & E.N.S. Mulhouse & I 1983 \\
\hline Fürstner, Professor A. & University of Mulheim & J 2002 \\
\hline Gallagher, Professor T. & University of Bath (Bristol) & I 1986 J 1998 \\
\hline Ghosez, Professor L. & Catholic University of Louvain & \begin{tabular}{|l|} 
Cardiff 1980 J 1983 \\
I 1988, 2000 \\
\end{tabular} \\
\hline Gibson, Professor S.E. & King's College, London & \begin{tabular}{|l|}
$\mathrm{J}$ \\
2001 \\
\end{tabular} \\
\hline Gilchrist, Dr. T. & University of Liverpool & Cardiff 1980 \\
\hline Golding, Professor B. & University of Newcastle & I 1987 \\
\hline Gommper, Professor R. & University of Munich & A 1973 \\
\hline Grigg, Professor R. & University of Leeds & Hull 1984 J 1988 \\
\hline Hale, Professor K.J. & University College, London & I 1998 \\
\hline Harrowven, Professor D. & University of Southampton & J 2006 \\
\hline Harwood, Professor L. & University of Reading & J 1997 I 2005 \\
\hline Hegarty, Professor A.F. & University of Dublin & Hull 1984 J 1996 \\
\hline Heimgartner, Professor H. & University of Zürich & Cardiff 1980 \\
\hline
\end{tabular}




\begin{tabular}{|c|c|c|}
\hline Helmchen, Professor G. & University of Heidelberg & J 1992 \\
\hline Heusler, Dr. K. & Ciba-Geigy, Basle & J 1974 \\
\hline Holmes, Dr. A.B. & University of Cambridge & I 1990 \\
\hline Hoppe, Professor D. & University of Münster & I 1996 \\
\hline Huisgen, Professor R. & University of Munich & I 1988 \\
\hline Husson, Professor H.-P. & C.N.R.S. Gif-sur-Yvette & I 1990 \\
\hline Illuminati, Professor G. & University of Rome & A 1973 \\
\hline Jackson, Professor R. & University of Sheffield & J 2004 \\
\hline Jackson, ProfessorA.H. & University College, Cardiff & J 1979 \\
\hline Jefford, Professor C.W. & University of Geneva & I 1991 \\
\hline Johnson, Professor A.W. & University of Sussex & A 1973 J 1980 \\
\hline Jones, Dr. D.W. & University of Leeds & Hull 1984 \\
\hline Jones, Professor G. & University of Keele & J 1988 \\
\hline Jones, Professor K. & University of Kingston & J 2000 \\
\hline Joule, Dr. J. & University of Manchester & I 1999 \\
\hline Katritzky, Professor A.R. & University of Florida & \begin{tabular}{|l|} 
Edinburgh 1979 \\
Hull $1984 \mathrm{~J} 1988$ \\
\end{tabular} \\
\hline Kerr, Professor W.J. & University of Strathclyde & I 2005 \\
\hline Kirby, Professor G.W. & University of Glasgow & Edinburgh $1979 \mathrm{~J} 1992$ \\
\hline Knight, Professor D.W. & University of Cardiff & I 19962002 \\
\hline Kocienski, Professor P. & University of Glasgow & I 1992I 2000 \\
\hline L’abbé, Professor G. & Catholic University of Louvain & $\begin{array}{l}\text { Cardiff } 1978 \text { Aston } 1982 \\
\text { Hull } 1984\end{array}$ \\
\hline Leonard, Dr. J. & University of Salford & J 2001 \\
\hline Leonard, Professor N.J. & University of Illinois & Welwyn 1970 \\
\hline Ley, Professor S,V. & University of Cambridge & I 1989 \\
\hline List, Professor B., & Max-Planck-Institute & I 2005 \\
\hline Lloyd, Dr. D.M.G. & University of St. Andrews & Hull 1984 \\
\hline Lozac'H, Professor N. & University of Caen & A 1973 \\
\hline Lund, Professor H. & University of Aarhus & J 1987 \\
\hline Lygo, Dr. B. & University of Nottingham & I 2002 \\
\hline Maier, Professor G. & University of Giessen & J 1990 \\
\hline Makosza, Professor M. & Polish Academy of Science & J 1989 \\
\hline Mann, Professor J. & $\begin{array}{l}\text { University of Reading } \\
\text { Queens University, Belfast }\end{array}$ & J 1994, 2006 \\
\hline Maquestiau, Professor A. & University of Mons & A 1973 \\
\hline
\end{tabular}




\begin{tabular}{|c|c|c|}
\hline Markl, Professor G. & University of Regensburg & A 1973 \\
\hline Marko, Professor I.E. & Catholic University of Louvain & I 1997 \\
\hline McKervey, Professor M.A. & Queen’s University, Belfast & I 1994 \\
\hline McKillop, Professor A. & University of East Anglia & J 1982 I 1991 \\
\hline Michael, Dr.J.D. & Hoechst UK & Hull 1984 \\
\hline Molina, Professor P & University of Murcia & J 1993 \\
\hline Moody, Professor C.J. & \begin{tabular}{|l}
$\begin{array}{l}\text { University of Loughborough } \\
\text { (Exeter) }\end{array}$ \\
\end{tabular} & J 1991 I 1996, 2003 \\
\hline Motherwell, Professor W.B. & University College, London & J 1994 \\
\hline Müller, Professor K. & Hofmann-La Roche, Basle & I 1993 \\
\hline Murphy, Professor J.A. & University of Strathclyde & I 1997 \\
\hline Newton, Dr. R.F. & Glaxo & J 1988 \\
\hline Ollis, Professor W.D. & University of Sheffield & J 1990 \\
\hline Page, Professor P.C.B. & University of Loughborough & I 1997 \\
\hline Pandit, Professor U.K. & University of Amsterdam & J 1995 \\
\hline Parker, Professor D. & University of Durham & I 1995 \\
\hline Parsons, Professor P.J. & University of Reading & J 1991 \\
\hline Paterson, Professor I. & University of Cambridge & J 2004 \\
\hline Pattenden, Professor G. & University of Nottingham & I 1999 \\
\hline Pfaltz, Professor A. & University of Basle & I 2001 \\
\hline Pfleiderer, Professor W. & University of Konstanz & I 1974 \\
\hline Potter, Professor B.V.L. & University of Bath & J 1999 \\
\hline Professor Diederich, F. & ETH Zurich & J 1998 \\
\hline Quéginer, Professor D.G. & University of Rouen & J 1984, 2003 \\
\hline Ramage, Professor R. & University of Salford & Cardiff 1978 \\
\hline Ramsden, Professor C,A. & University of Keele & J 1999 \\
\hline Rees, Professor C.W. & Imperial College & Hull 1984 J 1988 \\
\hline Rees, Professor C.W.B. & King's College, London & J 1986, 1997 \\
\hline Reinhoudt, Professor D.N. & Twente University of Technology & I 1981 \\
\hline Reisseg, Professor H.-U. & Free University, Berlin & J 2004 \\
\hline Robins, Professor D.J. & University of Glasgow & I 1994 \\
\hline Robins, Professor R.K. & University of Utah & Aston 1982 \\
\hline Schaumann, Professor E. & University of Hamburg & J 1982 \\
\hline Simpkins, Professor N. & University of Nottingham & $\mathrm{J} 2002$ \\
\hline Simpson, Professor T.J. & University of Bristol & J 1993 \\
\hline Smalley, Dr. R.K. & University of Salford & J 1983 \\
\hline
\end{tabular}




\begin{tabular}{|c|c|c|}
\hline Smith, Professor A.B & University of Pennsylvania & M 2001 \\
\hline Smith, Professor K. & University of Swansea & I 1998 \\
\hline Smith, Professor K.M. & University of California, Davis & Cardiff 1980 \\
\hline Snieckus, Professor V. & Queen’s University, Canada & I 1990 I 2000 \\
\hline Sondheimer, Professor F. & University College London & J 1973 \\
\hline Speckamp, Professor W.N. & University of Amsterdam & I 19871994 \\
\hline Spivey, Dr.A & Imperial College & I 2003 \\
\hline Stanovnik, Professor B. & University of Ljubljana & I 1974 \\
\hline Stoddart, Professor J.F. & University of Birmingham & I 1991 \\
\hline Stoodley, Professor R. & UMIST & I 1985 J 2000 \\
\hline Storr, Dr. R.C. & University of Liverpool & J 1995 \\
\hline Suschitzky, Professor H. & University of Salford & Edinburgh $1979 \mathrm{~J} 1988$ \\
\hline Takeuchi, Professor Y. & University of Tokyo & J 1973 \\
\hline Tennant, Dr. G. & University of Edinburgh & J 1988 \\
\hline Thomas, Professor E.J. & University of Manchester & J 1992 \\
\hline Ugen, Professor D. & University of Strasbourg & J 2005 \\
\hline van der Plas, Professor H.C. & $\begin{array}{l}\text { Landbouwhogeschool. } \\
\text { Wageningen }\end{array}$ & A 1973 \\
\hline van Leusen, Professor A.M. & University of Groningen & A 1974 \\
\hline Viehe, Professor H.G. & University of Louvain & J 1990 \\
\hline Vogel, Professor E. & University of Munich & Welwyn 1970 \\
\hline Waldmann, Professor H. & University of Karlsruhe & J 1996 \\
\hline Walker, Professor R.T. & University of Birmingham & Aston 1982 \\
\hline Wamhoff, Professor H. & University of Bonn & I 1987 \\
\hline Wentrup, Professor C. & University of Marburg & J 1979 \\
\hline Whiting, Dr. D.A. & University of Nottingham & J 1993 \\
\hline Wills, Professor M. & University of Warwick & I 2001 \\
\hline Winterfeldt, Professor E. & University of Hamburg & I 1992 \\
\hline Young, Professor D.W. & University of Sussex & J 1996 \\
\hline Zard, Professor S.Z. & C.N.R.S. Gif-sur-Yvette & J 1997 I 1999 \\
\hline Zwanenburg, Professor B. & University of Nijmegen & I 1989 \\
\hline
\end{tabular}

$\mathrm{A}=\mathrm{CS}$ or RSC Autumn meeting, $\mathrm{I}=$ Industrial meeting, $\mathrm{J}=$ January meeting, $\mathrm{M}=$ Miscellaneous, $\mathrm{PG}=$ Postgraduate Meeting 
Appendix 3. Principal Lecturers at International Meetings*

\begin{tabular}{|c|c|c|}
\hline Aggarwal, Professor V.K. & University of Bristol & Grasmere 17 \\
\hline Alder, Dr. R.W. & University of Bristol & Grasmere 10 \\
\hline Alexakis, Professor A. & Université Pierre et MarieCurie & Grasmere 12 \\
\hline Anastassiou, Professor A.G. & Syracuse University & Grasmere 4 \\
\hline Andersson, Professor P. & University of Uppsala & Anglo-Italian 10 \\
\hline Arcamone, Professor F. & Pomezia & Anglo-Italian 4 \\
\hline Arigoni, Professor D. & ETH-Zentrum & Anglo-Italian 5 \\
\hline Ashe, Professor A.J. & University of Michigan & Grasmere 3 \\
\hline Bachi, Professor M. & Weizman Institute, Israel & Grasmere 15 \\
\hline Baldwin, Professor J.E. & University of Oxford & Grasmere 3.8 \\
\hline Barluenga, Professor J. & University of Ovieda & Grasmere 15 \\
\hline Barrett, Professor A.G.M. & Imperial College & Grasmere 12 \\
\hline Battersby, ProfessorA.R. & University of Cambridge & Grasmere 6 \\
\hline Beak, Professor P. & University of Illinois & Grasmere 8 \\
\hline Bergman, Professor J. & $\begin{array}{l}\text { Royal Institute of Technology, } \\
\text { Stockholm }\end{array}$ & $\begin{array}{l}\text { Grasmere } 10 \\
\text { Anglo-Italian } 9\end{array}$ \\
\hline Black, Professor D. St.C. & University of New South Wales & Grasmere 11 \\
\hline Boger, Professor D.L. & Purdue University & Grasmere 9 \\
\hline Bosch, ProfessorJ. & University of Barcelona & Grasmere 14 \\
\hline Boyle, Dr. P. & Trinity College, Dublin & Anglo-Italian 6 \\
\hline Buchardt, Professor O. & University of Copenhagen & Grasmere 2 \\
\hline Bulman-Page, Professor P. & University of Loughborough & Anglo-Italian 9 \\
\hline Burger, Professor K. & Technical University of Munich & Grasmere 6 \\
\hline Cadogan. Professor J.I.G. & University of Edinburgh & Grasmere 1 \\
\hline Cardillo, Professor G. & University of Bologna & Anglo-Italian 8 \\
\hline Ceder, Professor O. & Chalmers Institute, Gothenburg & Grasmere 7 \\
\hline Chambers, Professor R.D. & University of Durham & Anglo-Italian 3 \\
\hline Chiacchio, Professor U. & University of Catania & Anglo-Italian 10 \\
\hline Ciufolina, Professor M.A. & University of Lyon & Grasmere 16 \\
\hline Comins, Professor D.L. & North Carolina State University & Grasmere 11,17 \\
\hline Cook, ProfessorJ.M. & University of Milwaukee & Grasmere 15 \\
\hline Cossy, Professor J. & ESPCI, Paris & Anglo-Italian 10 \\
\hline Cruciani, Professor G. & University of Perugia & Anglo-Italian 8 \\
\hline Curci, Professor R. & University of Bari & Anglo-Italian 7 \\
\hline Curran. Professor D.P. & Pittsburgh University & Grasmere 12 \\
\hline
\end{tabular}




\begin{tabular}{|c|c|c|}
\hline Davis, Professor F.A. & Temple University & Grasmere 13 \\
\hline Denmark, Professor S. & University of Illinois & Grasmere 16 \\
\hline Desimoni, Professor G. & University of Pavia & Anglo-Italian 3 \\
\hline Dolling, Dr. U.-H. & Merck, Sharp, and Dohme & Grasmere 9 \\
\hline Dondoni, Professor A. & University of Ferrara & $\begin{array}{l}\text { Anglo-Italian } 2 \\
\text { Grasmere } 9\end{array}$ \\
\hline Eschenmoser, Professor A. & ETH, Zurich & Anglo-Italian 2 \\
\hline Feringa, Professor B. & University of Groningen & Grasmere 16 \\
\hline Firestone, Dr.R.A. & Merck, Sharp, and Dohme & Grasmere 5 \\
\hline Flitsch, Professor W. & University of Münster & Grasmere 3,10 \\
\hline Florio, Professor S. & University of Bari & Anglo-Italian 9 \\
\hline Fringuelli, Professor F. & University of Perugia & Anglo-Italian 10 \\
\hline Fu, Professor G. & MIT & Grasmere 15 \\
\hline Fuchs, Professor B. & Tel-Aviv University & Grasmere 6 \\
\hline Fürstner, Professor A. & Max-Planck Institute, Mulheim & Grasmere 14 \\
\hline Gallagher, Professor T. & University of Bristol & Anglo-Italian 9 \\
\hline Gawley, Professor R.E. & University of Miami & Grasmere 14 \\
\hline Ghosez, Professor L. & University of Louvain & Grasmere 13 \\
\hline Gibson, Professor S.E & Imperial College & Anglo-Italian 10 \\
\hline Gilchrist, Dr. T. & University of Liverpool & Grasmere 16 \\
\hline Gommper, Professor R. & University of München & Grasmere 8 \\
\hline Grieco, Professor P. & Montana State University & Grasmere 16 \\
\hline Grigg, Professor R. & $\begin{array}{l}\text { Queens University, Belfast } \\
\text { University of Leeds }\end{array}$ & $\begin{array}{l}\text { Grasmere 5,16 } \\
\text { Anglo-Italian 2,6 }\end{array}$ \\
\hline Guanti, Professor G. & University of Genova & Anglo-Italian 9 \\
\hline Hamilton, Professor A.D. & University of Pittsburgh & Grasmere 11 \\
\hline Heimgartner, Professor H. & University of Zurich & Grasmere 10 \\
\hline Heller, Professor H. & UWIST & Grasmere 8 \\
\hline Holmes, Professor A.B. & University of Cambridge & \begin{tabular}{|l|} 
Grasmere 12,16 \\
Anglo_Italian 7 \\
\end{tabular} \\
\hline Houk, Professor K.N, & University of Pittsburgh & Grasmere 7 \\
\hline Hudlicky, Professor T. & Virginia Polytechnic & Grasmere 11 \\
\hline Huisgen, Professor R. & University of München & Grasmere 6 \\
\hline Hunig, Professor S. & University of Wurzburg & Grasmere 1 \\
\hline Jäger, Professor V. & University of Wurzburg & Grasmere 8 \\
\hline Johnson, Dr. A.P. & University of Leeds & Anglo-Italian 2 \\
\hline Jones, Professor G. & University of Keele & Grasmere 11 \\
\hline
\end{tabular}




\begin{tabular}{|l|l|l|}
\hline Jones, Professor R.C.F. & University of Loughborough & $\begin{array}{l}\text { Anglo-Italian 7 } \\
\text { Grasmere 17 }\end{array}$ \\
\hline Jorgensen, Professor K.A. & University of Aarhus & Anglo-Italian 8 \\
\hline Jungheim, Dr.L. & Lilly Research & Grasmere 8 \\
\hline Kametani, Professor T. & Tohoku University & Grasmere 4 \\
\hline Katritzky, Professor A.R. & University of East Anglia & Grasmere 1, 9, 14, 17 \\
\hline Kay, Dr. I.T. & ICI Jealotts Hill & Grasmere 7 \\
\hline Kellogg, Professor R.M. & University of Groningen & Grasmere 1,9 \\
\hline Kelly, Dr. R.C. & Upjohn Company & Grasmere 9 \\
\hline Kirby, Professor G.W. & University of Glasgow & Grasmere 2 \\
\hline Knölker, Professor H.J. & University of Karlsruhe & Grasmere 12 \\
\hline Kocienski, Professor P.J. & University of Glasgow & Grasmere 13 \\
Anglo-Italian 10
\end{tabular}




\begin{tabular}{|c|c|c|}
\hline Myers, Professor A.G. & Harvard University & Grasmere 17 \\
\hline Nicolau, Professor K.C. & University of Pennsylvania & Grasmere 6 \\
\hline Ninomiya, Professor I. & Kobe Women's College & Grasmere 6,7 \\
\hline Novi, Professor M. & University of Genoa & Anglo-Italian 4 \\
\hline Ollis, Proessor W.D. & University of Sheffield & Grasmere 5 \\
\hline Oppolzer, Professor W. & University of Geneva & Anglo-Italian 2 \\
\hline Overman, Professor L. & University of California, Irvine & $\begin{array}{l}\text { Anglo-Italian } 2 \\
\text { Grasmere } 8\end{array}$ \\
\hline Padwa, Professor A. & Emory University & Grasmere 2, 9,12 \\
\hline Pagani, Professor G.A. & University of Milan & $\begin{array}{l}\text { Anglo-Italian } 4 \\
\text { Grasmere } 13\end{array}$ \\
\hline Paquette, Professor L.A. & Ohio State University & Grasmere 10 \\
\hline Parsons, Professor P. & University of Sussex & Anglo-Italian 6 \\
\hline Paterson, Professor P. & University of Cambridge & Grasmere 17 \\
\hline Pattenden, Professor G. & University of Nottingham & Anglo-Italian 4, 8 \\
\hline Pedulli, Professor G.F. & University of Bologna & Anglo-Italian 6 \\
\hline Potts, Professor K.T. & Rensselaer Polytechnic Institute & Grasmere 3 \\
\hline Pfaltz, Professor A. & Max Planck Institute, Mannheim & Grasmere 13 \\
\hline Quast, ProfessorH. & University of Wurzburg & Grasmere 3 \\
\hline Rees, Professor C.W. & University of Liverpool & Grasmere $1,8,11$ \\
\hline Regitz, Professor M. & Univerity of Kaiserslauten & Grasmere 9 \\
\hline Reid, Professor D.H. & University of St. Andrews & Grasmere 11 \\
\hline Roberts, Professor S.M. & University of Exeter & Anglo-Italian 3 \\
\hline Ruano, Professor J.L.G. & University of Madrid? & Anglo-Italian 8 \\
\hline Rutjes, Professor F.J.T. & Radboud University, Nijmegen & Grasmere 17 \\
\hline Sanders, Dr. J.K.M. & University of Cambridge & Grasmere 12 \\
\hline Sannicolò, Professor F. & University of Milan & Anglo-Italian 6 \\
\hline Schill, Professor G. & University of Freiburg & Grasmere 1 \\
\hline Schröder, Professor G. & University of Karlsruhe & Grasmere 3 \\
\hline Scolastico, Professor C. & University of Milan & Anglo-Italian 7 \\
\hline Scott, Professor A.I. & Texas A. and M. University & Grasmere 4 \\
\hline Shipman, Professor M. & University of Warwick & Grasmere 17 \\
\hline Skell, Professor P.S. & Pennsylvania State University & Grasmere 2 \\
\hline Smith, Professor A.B. & University of Pennsylvania & Grasmere 13 \\
\hline Snider, Professor B. & Brandeis University & Grasmere 16 \\
\hline Snieckus, Professor V. & University of Waterloo & Grasmere 5 \\
\hline Spagnolo, Professor P. & University of Potenza & Anglo-Italian 3 \\
\hline
\end{tabular}




\begin{tabular}{|c|c|c|}
\hline Speckamp, Professor N. & & Anglo-Italian 2 \\
\hline Staab, Professor H.A. & University of Heidelberg & Grasmere 2 \\
\hline Stanovnik, Professor B. & University of Ljubljana & $\begin{array}{l}\text { Grasmere } 7 \\
\text { Anglo-Italian } 9\end{array}$ \\
\hline Steglich, Professor W. & University of Bonn & Grasmere 10 \\
\hline Stevens, Professor M.F.G. & University of Nottingham & Anglo-Italian 5 \\
\hline Streith, Professor J. & University of Mulhouse & Grasmere 1 \\
\hline Suschitzky, Professor H. & University of Salford & Grasmere 2 \\
\hline Sutherland, Professor I.O. & University of Liverpool & Grasmere 7 \\
\hline Taylor, Professor E.C. & Princeton University & Grasmere 5, 13, 15 \\
\hline Taylor, Professor R.J.K. & University of York & $\begin{array}{l}\text { Anglo-Italian } 5 \\
\text { Grasmere } 11,16 \\
\end{array}$ \\
\hline Thomas, Professor E.J. & University of Manchester & Grasmere 14 \\
\hline Tietze, Professor L.F. & $\begin{array}{l}\text { University of Göttingen } \\
\text { Georg-August University }\end{array}$ & $\begin{array}{l}\text { Grasmere } 11 \\
\text { Anglo-Italian } 5\end{array}$ \\
\hline Townsend, Professor L.B. & University of Michigan & Grasmere 6 \\
\hline Ugi, Professor I. & Technische Hochschule, München & Grasmere 1 \\
\hline van der Plas, Professor H.C. & Wageningen University & Grasmere 5 \\
\hline van Leusen, Professor A.M. & University of Groningen & Grasmere 4 \\
\hline Vasella, Professor A. & ETH-Zentrum, Zurich & Anglo-Italian 5 \\
\hline Vedejs, Professor E. & University of Michigan & Grasmere 14 \\
\hline Viehe, Professor H.G. & University of Louvain & Grasmere 4 \\
\hline Vogel, Professor E. & University of Cologne & Grasmere 3, 9 \\
\hline Warren, Dr. S.G. & University of Cambridge & Grasmere 14 \\
\hline Wasserman, Professor H.H. & Yale University & Grasmere 7 \\
\hline Weinreb, Professor S.M. & Pennsylvania State University & $\begin{array}{l}\text { Anglo-Italian } 2 \\
\text { Grasmere } 14 \\
\end{array}$ \\
\hline Wentrup, Professor C. & University of Lausanne & Grasmere 2, 7 \\
\hline Williams, Professor D.H. & University of Cambridge & Grasmere 13 \\
\hline Winterfeldt, Professor E. & Univerity of Hannover & Grasmere 5 \\
\hline Wipf, Professor P. & University of Pittsburgh & Grasmere 17 \\
\hline Woggon, Professor W-D. & University of Basle & Anglo-Italian 7 \\
\hline Wynberg, Professor H. & University of Groningen & Grasmere 1 \\
\hline Zhu, Professor J.P. & CNRS, Paris & Grasmere 17 \\
\hline
\end{tabular}

* Defined as lectures of length $>30$ minutes; most are one hour plenary lectures. There were 179 contributions of 30 minutes at Grasmere and Anglo-Italian meetings. 